\title{
EFFECT OF THIOPENTONE ON EMERGENCE REACTIONS TO KETAMINE ANAESTHESIA
}

\author{
J.A.O. MagbagbeOlA, M.B., CH.B.(BRIST.), F.F.A.R.C.S.I. AND \\ N.A. THOMAS, L.R.C.P.I., L.R.C.S.I., D.A.
}

Sfveral Clinical evaluations of ketamine and its different anaesthetic uses for surgical procedures have been documented. ${ }^{1-\tau}$ Its use as the sole anaesthetic agent continues to interest many workers because of the safety and simplicity of the technique, which can be employed either by single-handed doctors, or under special conditions such as in the case of burns and at the site of accidents. One of the major undesirable features of ketamine anaesthesia which has not been completely solved is the high incidence of emergence reactions in adult patients in the immediate recovery period. These reactions may be manifest, in varying degrees, as restlessness, hallucinations, often accompanied by irrational behaviour, and unpleasant dreams. The present study was undertaken in view of some success achieved in treating a few female patients with severe emergence reactions with a small dose of intravenous thiopentone.

This paper reports the effect of a small intravenous dose of thiopentone sodium at the end of operation on the incidence and severity of emergence reactions.

\section{METHODS}

One hundred healthy adult Nigerian female patients scheduled for minor gynaecological operations were selected at random for study. Premedication was with intramuscular atropine sulphate $0.6 \mathrm{mg}$ given about 45 minutes prior to induction of anaesthesia. After the patients were positioned on the operating table, cleaned and draped, anaesthesia was induced with intravenous ketamine $2.0 \mathrm{mg} / \mathrm{Kg}$ body weight. Often no supplementary dose of ketamine was required but whenever this was necessary a dose of $20 \mathrm{mg}$ was given intravenously. No other anaesthetic agents were administered and the patients were allowed to breathe room air. Intravenous thiopentone sodium $150 \mathrm{mg}$ was given to each of 50 patients at the end of operation before they were moved from the operating table. This group of patients constituted the "treated group." The remaining 50 patients had no thiopentone immediately after the operation and they served as the control or the "untreated group."

All patients were observed post-operatively for the mode of recovery from anaesthesia, respiratory disturbance, retching or vomiting. They were not stimulated in any way. Routine pulse rate and blood pressure readings were not taken. Patients who showed severe emergence reactions during observation were given intravenous thiopentone, 100 to $150 \mathrm{mg}$. All patients were visited some hours after they had completely recovered from the effect of anaesthesia for evidence of nausea, vomiting and dreams.

Department of Anaesthesia, University College Hospital, Ibadan, Nigeria. 
TABLE I

Details of Patients

\begin{tabular}{lcc}
\hline & Treated Group & Control Group \\
\cline { 2 - 3 } No. of Patients & 50 & 50 \\
Age (years) Mean & 37.4 & 39.1 \\
S.D. & \pm 5.9 & \pm 7.2 \\
Weight (Kg) Mean & 56.3 & 60.1 \\
S.D. & \pm 8.2 & \pm 7.3 \\
\hline
\end{tabular}

TABLE II

Distribution of EMERGENCE Reactions

\begin{tabular}{lcccr} 
& & \multicolumn{3}{c}{ Emergence reactions } \\
\cline { 3 - 5 } Groups & Total & Severe & Moderate & Mild \\
\hline Treated & 3 & 0 & 2 & 1 \\
Control & 18 & 10 & 5 & 3 \\
\hline
\end{tabular}

TABLE III

Distribution of Other Side Effects

\begin{tabular}{lcc}
\hline & \multicolumn{2}{c}{ Patients } \\
\cline { 2 - 3 } & Treated & Control \\
\hline Dreams & & \\
$\quad$ Pleasant & 1 & 11 \\
$\quad$ Unpleasant & 0 & 7 \\
$\quad$ Uncertain/Inability to recall & 0 & 5 \\
Emetic Sequelae & & \\
$\quad$ Nausea & 3 & 2 \\
$\quad$ Retching & 1 & 0 \\
$\quad$ Voniting & 2 & 1 \\
Respiratory upset & 0 & 0 \\
\hline
\end{tabular}

\section{RESULTS}

Table I shows the details of the patients. Both groups are comparable with regard to age and body weight. The mean duration of operation was 8.3 minutes (range 6 to 15 ).

The incidence and severity of emergence reactions are illustrated in Table II. Eighteen patients ( 36 per cent) in the control group showed emergence reactions. These were severe in 10 , moderate in 5 , and mild in 3 patients. In the treated group 3 patients ( 6 per cent) showed emergence reactions which were moderate in 2 and mild in one. This difference was statistically significant $(p<0.01)$. All the patients showing severe reactions were effectively treated with intravenous thiopentone.

Table III illustrates that the incidence of dreams was statistically higher in the control group than in the treated group $(\mathrm{p}<0.01)$.

The incidence of emetic sequelae (Table III) was slightly higher in the treated group than in the control group. There was no respiratory disturbance in either group. One patient in the control group complained of temporary "deafness." 


\section{Discussion}

The findings of this study confirm the high incidence of emergence reaction among adult female patients premedicated with atropine alone and anaesthetized with ketamine for minor operations. Thiopentone given intravenously at the end of operation has been shown to reduce the incidence and severity of emergence reactions and dreams significantly. Opiates and other tranquillizing agents have been omitted in order to determine the reactions due to ketamine alone. Corssen, Miyasaka and Domino ${ }^{8}$ have ascribed the cause of emergence upset during recovery from ketamine anaesthesia to premature efforts on the part of the staff to awaken the patients before they are fully orientated. These workers found that emergence reactions were almost absent when their patients were not stimulated after surgery. In the present study the overall incidence of 36 per cent of emergence reactions and 46 per cent of dreams in the control group is very high when compared with 6 per cent and 2 per cent respectively in the treated group.

Varying results have been published on the effects of drugs given pre-operatively or post-operatively to prevent emergence reactions after ketamine anaesthesia. ${ }^{9-15}$ Loh and his associates ${ }^{14}$ using diazepam $5 \mathrm{mg}$ intravenously at the end of minor surgical procedures did not find any difference in the incidence of emergence reactions from the group of patients who had received the same preoperative medication but had had no diazepam. Coppel and his colleagues ${ }^{15}$ using a Jarger dose of diazepam ( $1 \mathrm{mg} / 6 \mathrm{Kg}$ ) intravenously at the end of surgery, found the treatment effective in reducing the incidence of delirium and unpleasant dreams.

One other finding which needs to be mentioned is the absence of respiratory disturbance after the injection of thiopentone. It may be that since ketamine anaesthesia does not cause respiratory depression the small dose of thiopentone given later is not sufficient to affect respiration. Furthermore, all our patients were healthy and were not premedicated with opiates or other agents which depress respiration.

Although the incidence of emetic sequelae was slightly higher in the treated group, the difference is not significant.

The use of thiopentone in the prevention of emergence reactions to ketamine anaesthesia has a lot to recommend it. It is cheap, readily available, simple to administer and effective.

\section{SUMMARY}

One hundred female patients were studied, who were premedicated with atropine alone and anaesthetized with ketamine $2.0 \mathrm{mg} / \mathrm{Kg}$ as the sole agent for minor gynaecological procedures. Fifty of these patients received thiopentonc sodium $150 \mathrm{mg}$ intravenously at the end of the operation. The incidence and severity of emergence reactions was significantly less in this group of patients than in the group that had no thiopentone. The dose of thiopentone employed did not produce respiratory depression. 


\section{RÉSUMÉ}

Au cours d'opérations gynécologiques mineures, on a employé la Kétamine (2.0 $\mathrm{mg} / \mathrm{kg}$ ) comme seul agent anesthésique chez cent (100) patientes préalablement prémédiquées à l'Atropine.

A la fin de l'intervention, cinquante (50) d'entre elles reçurent $150 \mathrm{mg}$ de Thiopentone par voie endoveineuse. L'étude comparée des deux groupes a montré une réduction significative du nombre et de la gravité des réactions psychiâtriques d'émergence.

Aux doses utilisées, le Thiopentane n’a pourtant aucun effet indésirable sur la respiration.

\section{REFERENCES}

1. Corssen, G. \& Domino, E.F. Dissociative anaesthesia: further pharmacologic studies and first clinical experience with phencyclidine derivative Cl-581. Anesth. Analg. Curr. Res. 45: 29 (1966).

2. Falls, H.F., Hox, J.E., \& Conssen, G. Cl-581: an intravenous or intramuscular anaesthetic for office ophthalmic surgery. American Journal of Ophthalmology 61: 1093 (1966).

3. Roberts, F.W. A new intramuscular anaesthetic for small children: a report of clinical trials of CL-581. Anaesthesia 22: 23 (1967).

4. Phillips, L.A., Seruvatu, S.G., Rika, P.N., \& Trrixulu, U. Anaesthesia for the surgeonanaesthetist in difficult situations. The use of intramuscular 2 (o-chlorophenyl) 2 methylamino cyclohexanone $\mathrm{HCl}$ (Parke Davis Cl-581, Ketamine). Anaesthesia 25: 36 (1970).

5. Galloon, S. Ketamine for dilatation and curettage. Canad. Anaes. Soc. J. 18: 600 (1971).

6. Oduntan, S.A. \& Gool, R.Y. Clinical trial of ketamine (Cl-581). Canad. Anaesth. Soc. J. 17: $411(1970)$.

7. Magbagbeola, J.A.O. Experience with Cl-581. Value as induction agent and analgesic supplementation with light-general anaesthesia. The W.A.M.J. 22: 354 (1971).

8. Corssen, G., Mryasaka, M,, \& Domino, E.F. Changing concepts in pain control during surgery: dissociative anaesthesia with Cl-581. A progress report. Anaesth. Analg. Curr. Res. 47: 746 (1968).

9. Dundee, J.W., Bovill, J.G., Clarke, R.S.J., \& Pandit, S.K. Problems with ketamine in adults. Anaesthesia 26: 86 (1971).

10. Knox, J.W.D., Bovili, J.G., Clarke, R.S.J., \& Dundee, J.W. Clinical studies of induction agents. XXXVI: Ketamine. Brit. J. Anaesth. 42:875 (1970)

11. Sadove, M.S., Hatano, S., Zahed, B., Redlin, T., Arastounejad, P., \& Roman, V. Clinical study of droperidol in the prevention of the side effects of ketamine anaesthesia: a preliminary report. Anesth. Analg. Curr. Res. 50: 388 (1971).

12. Johnstone, M. The prevention of ketamine dreams. Anaesthesia and Intensive Care 1: $70(1972)$.

13. Ergbuth, P.H., Reiman, B., \& Klein, R.L. The influence of chlorpromazine, diazepam and droperidol on emergence from ketamine. Anesth. Analg. Curr, Res. 51: 693 (1972).

14. Loh, L., Singer, L., Morgan, M., \& Moore, P.H. Influence of diazepam on the emergence reactions following ketamine anaesthesia. Canad. Anaesth. Soc. J. 18: 421 (1972).

15. Coppel, D.L., Bovill, J.G., \& Dundee, J.W. The taming of ketamine. Anaesthesia 28: $293(1973)$. 